October 2017

\title{
Autonomy and Patient Care: To What Extent Should Children Make Their Own Decisions?
}

Heather G. Kuruvilla

Cedarville University

Follow this and additional works at: http:// digitalcommons.cedarville.edu/

bioethics_in_faith_and_practice

Part of the Bioethics and Medical Ethics Commons

DigitalCommons@Cedarville provides a publication platform for fully open access journals, which means that all articles are available on the Internet to all users immediately upon publication. However, the opinions and sentiments expressed by the authors of articles published in our journals do not necessarily indicate the endorsement or reflect the views of DigitalCommons@Cedarville, the Centennial Library, or Cedarville University and its employees. The authors are solely responsible for the content of their work. Please address questions to dc@cedarville.edu.

\section{Recommended Citation}

Kuruvilla, Heather G. (2017) "Autonomy and Patient Care: To What Extent Should Children Make Their Own Decisions?," Bioethics in Faith and Practice: Vol. 3 : No. 1 , Article 2.

DOI: $10.15385 /$ jbfp.2017.3.1.2

Available at: http://digitalcommons.cedarville.edu/bioethics_in_faith_and_practice/vol3/iss $1 / 2$ 


\section{Autonomy and Patient Care: To What Extent Should Children Make Their Own Decisions?}

Browse the contents of this issue of Bioethics in Faith and Practice.

Please read the Senior Editor's Preview for his insight about this article.

\section{About the Author(s)}

Heather Kuruvilla is managing editor for Bioethics in Faith and Practice, and serves as Professor of Biology at Cedarville University.

\section{Institution/Affiliation}

Cedarville University

\section{Abstract}

On June 14, 2016, 5-year old Julianna Snow died at home, in accordance with her stated wishes not to return to the hospital. Julianna suffered from a severe form of Charcot-Marie-Tooth disease, an inherited neurodegenerative disorder which, while not always lethal,1 had weakened her body to the extent that even a cold could be fatal.

Julianna's case raises important questions about patient autonomy and end-of-life care for children. The child did not wish to return to the hospital, and was willing to go to heaven instead.6 Though her parents respected her autonomy and honored her decision, the question remains: did Julianna have the decision-making capacity to make a life-or-death decision at such a young age? Are there cases where autonomy may have to be sacrificed in favor of other important ethical determinants, such as beneficence or non-maleficence?

\section{Keywords}

Autonomy, beneficence, minor, disability

\section{Creative Commons License}

\section{(c) (1) (9)}

This work is licensed under a Creative Commons Attribution-Noncommercial-No Derivative Works 4.0 License. 


\title{
From the Managing Editor
}

\section{Autonomy and Patient Care: To What Extent Should Children Make Their Own Decisions?}

\author{
Heather G. Kuruvilla, Ph.D. \\ Cedarville University
}

On June 14, 2016, 5-year old Julianna Snow died at home, in accordance with her stated wishes not to return to the hospital. Julianna suffered from a severe form of Charcot-Marie-Tooth disease, an inherited neurodegenerative disorder which, while not always lethal, ${ }^{1}$ had weakened her body to the extent that even a cold could be fatal. ${ }^{2}$

Julianna's story had previously been featured in USA Today ${ }^{3}$ as well as a number of online news sites, because of the controversy surrounding her wishes. On previous occasions, doctors had sustained her life only by subjecting her to invasive and painful procedures. Her parents therefore had frank discussions with their daughter about her preferences. ${ }^{4}$ Julianna decided she didn't want to go back to the hospital, so her parents used her input to forgo further painful interventions. ${ }^{5}$

Julianna's case raises important questions about patient autonomy and end-of-life care for children. The child did not wish to return to the hospital, and was willing to go to heaven instead. ${ }^{6}$ Though her parents respected her autonomy and honored her decision, the question remains: did Julianna have the decisionmaking capacity to make a life-or-death decision at such a young age? Are there cases where autonomy may have to be sacrificed in favor of other important ethical determinants, such as beneficence or nonmaleficence?

The question of whether minors have the capacity to make their own medical decisions remains controversial, an issue heavily influenced by cultural and religious traditions. For example, under Sharia law, a boy is considered a man once he has completed 15 lunar years, and a girl is considered a woman once she has completed 9 lunar years. ${ }^{7}$ In the United States, where 18 has long been considered the age of majority, the criminal justice system, as well as studies of adolescent psychology, have indicated that younger children, possibly as young as age 15, may be capable of understanding and making monumental health care decisions under certain conditions, where emotional arousal is minimized and they are not under peer pressure. ${ }^{8}$ Nonetheless, U.S. law continues to define minors as persons under 18 years of age. When a minor child wishes to refuse care, but the parent desires to continue pursuing it, the law generally sides with the parent. ${ }^{9}$

The situation can be even murkier when a mentally disabled person over the age of 18 wishes to refuse medical treatment. While in the past, a guardian would generally make medical decisions for the patient, the current trend in medicine favors "supported" decision making rather than "substitute" decision making. ${ }^{10}$ This trend is based partly on the United Nations Convention on the Rights of Persons with

Bioethics in Faith and Practice vol. 3, no. 1, pp. 1-3. ISSN 2374-1597

(C) 2017, Heather Kuruvilla, licensed under CC BY-NC-ND

(http://creativecommons.org/licenses/by-nc-nd/4.0/) 
Disability, as well as national laws. ${ }^{11}$ Such supported decision-making could include not only the right to refuse treatment, but the right to choose options such as physician-assisted suicide.

Minors and persons with disabilities evidence the Imago Dei as much as any other human being does. Treating these persons with the respect they deserve is certainly an admirable goal. However, we must tread cautiously in these matters. Patient autonomy is an important consideration - but is it paramount? Or are there cases where other considerations trump autonomy? Should our laws be changed to reflect current psychological theories regarding mature minors? The way these questions are answered will have lasting ramifications for the medical treatment of minors and mentally disabled persons.

Julianna's case, while extreme, may be part of a growing trend.

1 "NINDS Charcot-Marie-Tooth Disease Information Page." National Institute of Neurological Disorders and Stroke. Accessed January 12, 2016.

${ }^{2}$ Bowerman, Mary. "Parents to Honor 5-year-old Daughter's Decision of 'heaven' over 'hospital'" USA Today, October 28, 2015. Accessed January 12, 2016.

${ }^{3}$ Cohen, Elizabeth. "'Heaven Over Hospital': 5-year-old Julianna Snow Dies on Her Terms." CNN, June 20, 2016. Accessed July 18, 2017.

${ }^{4}$ Ibid.

${ }^{5}$ Ibid.

${ }^{6}$ Ibid.

${ }^{7}$ Parsapoor, Alireza, Mohammed-Bagher Parsapoor, Nima Rezaei, and Fariba Asghari. "Autonomy of Children and Adolescents in Consent to Treatment: Ethical, Jurisprudential and Legal Considerations." Iranian Journal of Pediatrics 24, no. 3 (2014): 241-48. Accessed January 12, 2016.

${ }^{8}$ Steinberg, Laurence. "Does Recent Research on Adolescent Brain Development Inform the Mature Minor Doctrine." The Journal of Medicine and Philosophy 38, no. 3 (2013): 256-67. Accessed January 12, 2016.

${ }^{9}$ Coleman, Doriane, and Philip Rosoff. "The Legal Authority of Mature Minors to Consent to General Medical Treatment." Pediatrics 131, no. 4 (2013): 786-93. Accessed January 12, 2016.

${ }^{10}$ Richardson, Genevra. "Mental Disabilities and the Law: From Substitute to Supported Decision-Making?" Current Legal Problems, 2012. doi:10.1093/clp/cus010.

${ }^{11}$ Gooding, Piers. "Supported Decision-Making: A Rights-Based Disability Concept and Its Implications for Mental Health Law." Psychiatry, Psychology and Law 20, no. 3 (2012): 431-51. Accessed January 12, 2016. doi: $10.1080 / 13218719.2012 .711683$. 


\section{Bibliography}

1. Bowerman, Mary. "Parents to Honor 5-year-old Daughter's Decision of 'heaven' over 'hospital'" USA Today, October 28, 2015. Accessed January 12, 2016.

2. Cohen, Elizabeth. "'Heaven Over Hospital': 5-year-old Julianna Snow Dies on Her Terms." CNN, June 20, 2016. Accessed July 18, 2017.

3. Coleman, Doriane, and Philip Rosoff. "The Legal Authority of Mature Minors to Consent to General Medical Treatment." Pediatrics 131, no. 4 (2013): 786-93. Accessed January 12, 2016.

4. Gooding, Piers. "Supported Decision-Making: A Rights-Based Disability Concept and Its Implications for Mental Health Law." Psychiatry, Psychology and Law 20, no. 3 (2012): 431-51. Accessed January 12, 2016. doi:10.1080/13218719.2012.711683.

5. "NINDS Charcot-Marie-Tooth Disease Information Page." National Institute of Neurological Disorders and Stroke. Accessed January 12, 2016.

6. Parsapoor, Alireza, Mohammed-Bagher Parsapoor, Nima Rezaei, and Fariba Asghari. "Autonomy of Children and Adolescents in Consent to Treatment: Ethical, Jurisprudential and Legal Considerations." Iranian Journal of Pediatrics 24, no. 3 (2014): 241-48. Accessed January $12,2016$.

7. Richardson, Genevra. "Mental Disabilities and the Law: From Substitute to Supported DecisionMaking?" Current Legal Problems, 2012. doi:10.1093/clp/cus010.

8. Steinberg, Laurence. "Does Recent Research on Adolescent Brain Development Inform the Mature Minor Doctrine." The Journal of Medicine and Philosophy 38, no. 3 (2013): 256-67. Accessed January 12, 2016. 